\title{
Even the smallest habitat patch matters: on the fauna of peat bogs
}

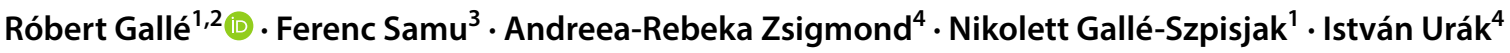

Received: 24 January 2019 / Accepted: 12 June 2019 / Published online: 11 July 2019

(c) The Author(s) 2019

\begin{abstract}
Peat bogs are highly endangered and very sensitive habitats in Central Europe. Their high water table, acidity and characteristic climate determine their specialized flora and fauna with numerous rare species. Peat bogs are threatened by soil erosion and nutrient infiltration due to forestry management or grazing. Several small, natural peat bogs exist in the Carpathians, mainly covered with birch and pine forests. Here we assessed the effect of geological location, peat bog size and tree species on the spider fauna. We collected spiders with pitfall traps in eight peat bogs in Eastern Transylvania. We identified several species of high nature conservation value, regarded to be rare in the Central-European fauna. We found higher species richness, abundance and diversity in birch forests than in pine forests. The open canopy of birch forests may allow open habitat specialists to occur in high densities in these forests. Species composition was affected by geological location, indicating that the regional fauna of peat bogs in different mountain ranges are isolated. However, we found no significant effect of habitat area on spider assemblages, the valuable tyrphophilic spider fauna was present even in the smallest peat bog. Peat bog spider fauna requires specific habitat conditions, we suggest that preserving hydrological properties and water quality even in the smallest bogs would conserve the specialized fauna.
\end{abstract}

Keywords Spiders $\cdot$ Species richness $\cdot$ Small habitat patch $\cdot$ Habitat island $\cdot$ Conservation $\cdot$ Araneae

\section{Introduction}

Wetland ecosystems provide both unique biodiversity and substantial ecosystem services, however they are globally decreasing in their condition and diversity through habitat loss, climate change and pollution (Keddy 2010). Peat bogs

Electronic supplementary material The online version of this article (https://doi.org/10.1007/s10841-019-00164-8) contains supplementary material, which is available to authorized users.

Róbert Gallé

galle.robert@gmail.com

1 MTA Centre for Ecological Research, Institute of Ecology and Botany, Lendület Landscape and Conservation Ecology, Alkotmány u. 2-4, Vácrátót 2163, Hungary

2 Department of Ecology, University of Szeged, Közép fasor 52, Szeged 6726, Hungary

3 Plant Protection Institute, Centre for Agricultural Research, Hungarian Academy of Sciences, P.O. Box 102, Budapest 1525, Hungary

4 Department of Environmental Sciences, Sapientia Hungarian University of Transylvania, Calea Turzii 4, 400193 Cluj-Napoca, Romania in particular, represent highly threatened wetland ecosystems (Spitzer and Danks 2006). Peat bogs are nutrient-poor (oligotrophic) habitats dominated by sphagnum moss, characterized by a high water table and low pH (Spitzer and Danks 2006; Battes et al. 2014). In bogs the slowly and incompletely decaying plant material builds up as peat. This naturally accumulated peat layer has an important role in carbon stocking worldwide (Urák et al. 2017). Peat bogs have postglacial origin. They were once typical landscape elements in Central Europe, but today, especially as a result of human influences (forest management activities, peat extraction, climate warming, secondary succession), the degradation of these habitats became pronounced (Doyle 1990; Buchholz 2016; Urák et al. 2017). As a consequence, nowadays peat bogs are highly endangered and very sensitive habitats in Central Europe (Charman 2002; Riecken et al. 2006). Their characteristic climate, hydrology, food scarcity and high acidity are limiting factors which determine their unique, specialized flora and fauna with rare and threatened species. For these reasons peat bogs are listed in Annex I of the European Habitats Directive as a priority habitat type (Scott et al. 2006; Haase and Balkenhol 2014). 
Peat bogs can be viewed as habitat islands, then studying their biota can show how these isolated habitat patches contribute to regional biodiversity, and how their size and geographical distribution affects their nature conservation value. Peat bogs are foremost islands of a very specific habitat and as such harbor a specialist arthropod fauna (Spitzer and Danks 2006). Species richness and composition of individual patches may depend on local factors, such as the size of the habitat patch and idiosyncratic differences in local vegetation, but also on the regional species pool. Large habitat patches may not support more arthropod species than small patches due to a higher frequency of generalist species in smaller fragments (Gibb and Hochuli 2002). However, species composition may differ significantly, with the total number of specialist species being generally higher in larger patches (Bonte et al. 2002).

Studying island biogeography of bogs is best done in regions where these habitat types occur in abundance and there is a considerable size variation among them. The spider fauna of Northern and Western European peat bogs is relatively well known (e.g. Kupryjanowicz et al. 1997; Koponen 2002; Relys et al. 2002; Buchholz 2016). Their fauna consist of cold-adapted species with preferences for wet habitat, several species were identified as tyrphobiontic (occur exclusively in bogs) or tyrphophilic species (characteristic bog species but not restricted to them, Spitzer and Danks 2006). Scott et al. (2006) suggested that the spider indicator species are a surrogate taxon for the conservation value of the peat bog invertebrate fauna. We have much less information on Central and Southern European peat bog spider faunas, but see Kurka (1990) for the Czech Republic, Stambuk and Erben (2002) for Croatia, Samu and Urák (2014), and references therein for Romania. By studying Transylvanian peat bogs we can collect crucial missing information and also answer ecological questions related to their isolated nature.

Peat bogs in Eastern Transylvania are located in the Carpathians between 400 and 1200 a.s.l. (Pop 1960). There are more than 25 peat bogs in the region scattered along several mountain ranges, ranging between 1 and 120 ha in size (Samu and Urák 2014). The dominant forest vegetation types of the bogs are scots pine and birch forests, with different habitat structure and presumably different invertebrate fauna (Eggleton et al. 2005).

The majority of the remaining peat bogs are small and degraded by soil erosion and nutrient infiltration due to intensive forestry management or grazing. Furthermore, the remaining peat bogs are situated in different mountain ranges (e.g. Mts. Nemira, Mts. Harghita). The lowlands between the mountains may constitute a geographical barrier resulting in disjunct distribution of mountain species (Mráz et al. 2007). The remaining few natural peat bogs are strictly protected and/or situated in remote areas where forest management is not feasible.
In the present study we focused on eight forested bogs in the Nemira and Harghita mountain ranges (Eastern Transylvania, Romania). The main questions of our study were: (1) are forested peat bog spider assemblages basically the same in the whole studied region or do the two different mountain ranges harbor distinct spider assemblages? (2) Do the spider assemblages of large bogs differ from that of the small bogs? (3) Do forest tree species has an effect on the spider fauna?

\section{Materials and methods}

\section{Study sites and spider sampling}

Our study was conducted in eight peat bogs in Eastern Transylvania, Romania, all are situated in remote areas and majority of the sampled bogs are hardly accessible. All sampling sites were situated in forest-bogs. Eastern Carpathian peat bogs consist of two main forest habitat types (1) relatively open birch forest (Vaccinio-Betuletum pubescentis Libbert 1933); (2) closed Scots pine forest (Vaccinio-Pinetum sylvestris Kleist 1929 em. Matuszkiewicz 1962). We established ten sampling sites, five sites in Scots pine and five sites in birch forest, one at each bog and the two largest bogs containing two sites, one site in pine forest and one in birch forest. The bogs were located in two mountain ranges Nemira and Harghita Mountains, at an elevation of 925-1040 and 1025-1080 m a.s.l., respectively (Fig. 1). All peat bogs are part of Natura 2000 ecological network. For exact position and detailed description of bogs please see Online Resources 1 and 2.

We applied pitfall traps consisting of plastic cups $(250 \mathrm{ml})$ with approximately $120 \mathrm{ml}$ of 50\% ethylene-glycol solution and some drops of detergent. Fifteen traps were arranged in each site in a $3 \times 5$ grid, keeping $10 \mathrm{~m}$ distance from each other. The traps were open between mid-June to mid-July in 2013. Arthropods were sorted and conserved in 70\% ethanol-solution. Spiders were identified under stereoscopic microscope, using standard keys (Nentwig et al. 2017). The nomenclature follows the World Spider Catalog (Platnick 2018). The juvenile individuals were identified up to family level but were not considered for statistical analyses.

\section{Data analysis}

Data of the pitfall traps in each sampling site were pooled prior to the analyses. Using species richness and abundance as response variables, respectively, we tested the effect of forest type, peat bog size and mountain range with mixedeffect general linear models (GLMM) with a Poisson error term, and with a negative binomial error term if we detected overdispersion in the data (lme4 package: version 1.1.12, glmer and glmer.nb functions, respectively). To incorporate 


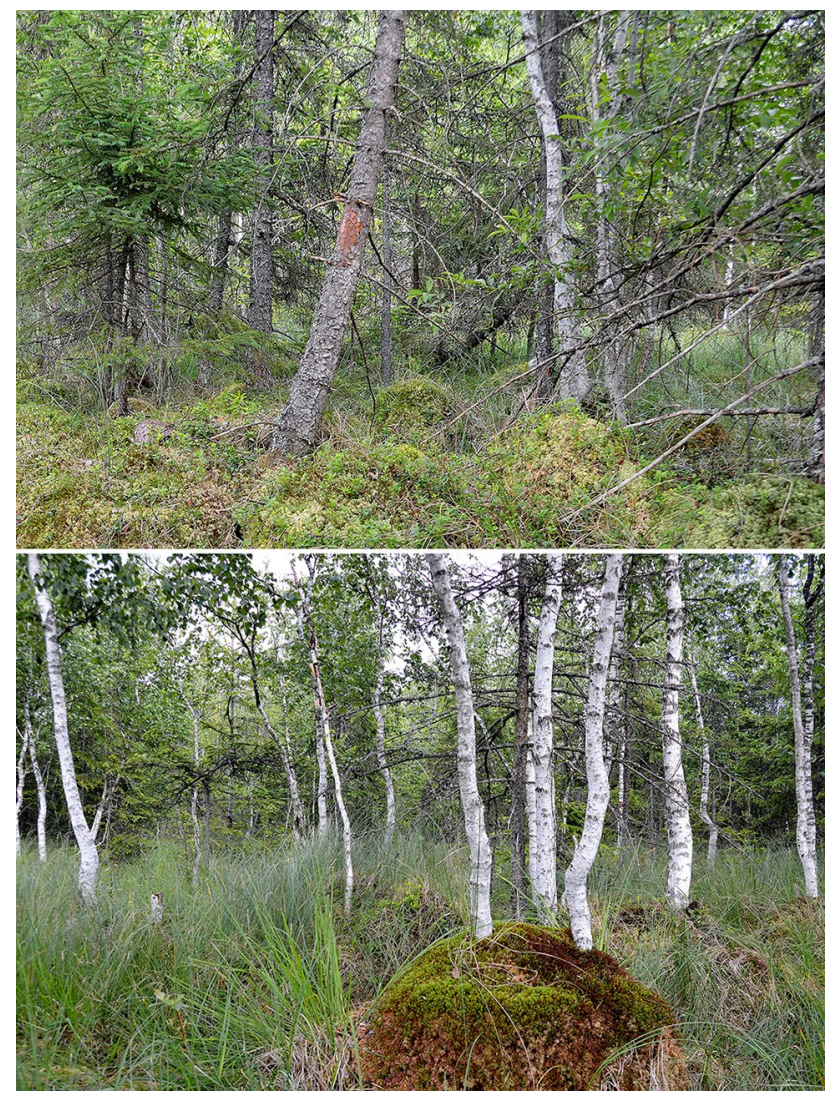

Fig. 1 Two sampled habitat types: pine forest bog (above) and birch forest bog (below)

possible effect of pitfall trap loss, the number of intact traps was used as random effect. If we found significant effect of forest type, we tested whether spider species diversity differed significantly among the two forest habitat types with constructing individual-based rarefaction curves and their respective 95\% lower and upper confidence limits (iNEXT package, Hsieh et al. 2016).

Spider-abundance data were Hellinger transformed prior to multivariate analysis (Legendre and Gallagher 2001). We used non-metric multidimensional scaling (NMDS, VEGAN package, Oksanen et al. 2015) to visualize the ordination structure of the samples based on the community composition. The ordination was based on the Bray-Curtis dissimilarity matrix with a maximum number of 100 random starts. To test whether habitat, size and mountain range had a significant effect on species composition, a permutational multivariate analysis of variance (ADONIS) was conducted using Bray-Curtis distance matrix and 5000 Monte-Carlo randomizations.

If we found significant effect habitat types and mountain ranges on species composition, we used indicator species analysis to identify species that have a high affinity for the different habitat types and mountain ranges, respectively (labdsv package, Roberts 2015). The number of significant species was low, thus we chose to set the probability to $\mathrm{p}<0.05$. The statistical calculations were performed using the software R (version 3.3.2) (R Core Team 2016).

\section{Results}

\section{Patterns in species abundance and richness}

During the sampling period, the total number of adult ground-dwelling spiders trapped in birch forest was 716 belonging to 71 species and we collected 501 spiders of 47 species in pine forests (Online Resource 3 of Supplementary Material).

Forest type strongly affected both species richness and abundance of spiders, however peat bog size and mountain range had no significant effect (Table 1). Rarefaction curves showed non-overlapping confidence intervals and revealed that birch forests had higher diversity than pine forests (Fig. 2). However, the steep rarefaction curves suggested that the collections were incomplete and additional sampling would yield new species.

\section{Spider assemblage composition}

All dominant species were wolf spiders (Lycosidae, Araneae). From this family we collected more than 100 individuals of Trochosa spinipalpis (F. O. P.-Cambridge, 1895), Piratula hygrophila (Thorell, 1872), Pirata uliginosus (Thorell, 1856) and Pardosa sphagnicola (Dahl, 1908). We collected several species (from various families) of high nature conservation value, regarded to be rare in the
Table 1 Summary table for GLMM results for spider abundance and species richness models

\begin{tabular}{llrl}
\hline & Forest type (birch/pine) & Peat bog size (small/large) & $\begin{array}{l}\text { Mountain range } \\
\text { (Nemira/Hargh- } \\
\text { ita) }\end{array}$ \\
\hline Species richness & $0.385 \pm 0.292^{* *}$ & $-0.239 \pm 0.448$ & $-0.001 \pm 0.437$ \\
Abundance & $0.264 \pm 0.192 * *$ & $0.061 \pm 0.248$ & $-0.346 \pm 0.469$ \\
\hline
\end{tabular}

Model parameter estimates $\pm 95 \% \mathrm{CI}$ and significance levels given

Significance levels: $* *<0.01$ 


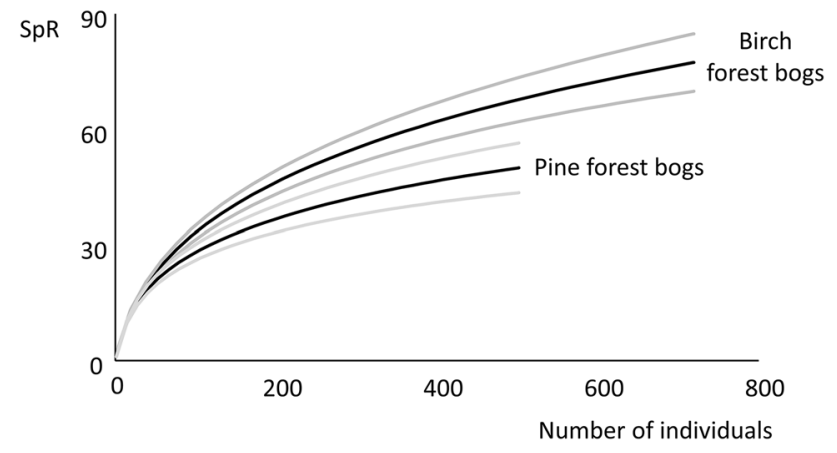

Fig. 2 Rarefaction curves of birch and pine forest bogs. Black line represent rarefaction curves, grey line are the corresponding $95 \%$ confidence intervals. $S p R$ species richness

Central-European fauna (Weiss and Urák 2000; Buchar and Ruzicka 2002), such as Notioscopus sarcinatus (O. P.-Cambridge, 1873), Neon reticulatus (Blackwall, 1853), Lessertinella carpatica Weiss, 1979, Peponocranium ludicrum (O. P.-Cambridge, 1861), Robertus scoticus Jackson, 1914, Cnephalocotes obscurus (Blackwall, 1834). Anguliphantes tripartitus (Miller and Svaton, 1978) was new to the Romanian spider fauna.

The species composition of the peat bogs situated in separate mountain ranges differed significantly (ADONIS, $\mathrm{F}=2.445, \mathrm{p}<0.020)$. However, we did not detect the effect of peat bog size (ADONIS, $\mathrm{F}=0.576$, N.S.), and we did not find any significant difference between birch and pine forest spider assemblages (ADONIS, F $=0.543$, N.S.). High overlap between the spiders assemblages of pine and birch forests was also revealed by the non-metric multidimensional scaling (Fig. 3, stress $=10.58$ ).

The two mountain ranges had their own significant indicator species. Inermocoelotes inermis (L. Koch, 1855) was a significant indicator of Harghita Mountains, IndVal =1; $\mathrm{p}=0.004$, and several species had significant indicator value for Nemira Mountains, such as Agyneta rurestris (C. L. Koch, 1836), IndVal $=1, p=0.006$, Walckenaeria atrotibialis (O. P.-Cambridge, 1878), IndVal $=0.978, \mathrm{p}=0.009$, Neriene radiata (Walckenaer, 1841), IndVal $=0.750$, $\mathrm{p}=0.04$.

\section{Discussion}

In the present study, we analyzed the spider assemblages of East-Carpathian peat bogs. Although based on only eight bogs and ten sampling sites, our results clearly showed that East-Carpathian peat bogs have a special spider fauna with numerous rare species. The dominant spider species of peat bogs were either tyrphobiontic or tyrphophilic species with preference for humid peat bog habitats (Buchar and Ruzicka

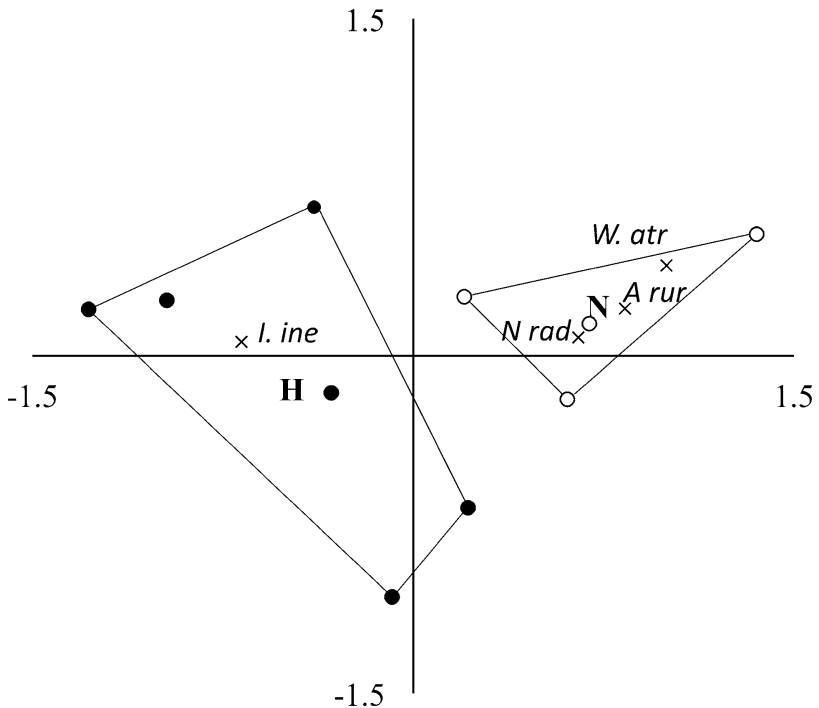

Fig. 3 Scatterplot of the non-metric multidimensional scaling model. Black circles indicate Harghita mountain range $(\mathrm{H})$, open circles indicate Nemira mountain range $(\mathrm{N})$. Significant indicator species are shown with crosses and abbreviated with the first letter of genus name and first three letters of the species name, (see Online Resource 3 of Supplementary Material and text for details)

2002; Buchholz 2016). Several further species were exclusively found in peat bogs in Romania (Gallé and Urák 2001, 2002, 2006; Urák and Samu 2008) also underpinning the conservational value of spider fauna of peat bogs. Regionality played an important role in shaping spider assemblages, as the two studied mountain ranges had significantly different assemblages. Spider fauna of small bogs was similar to that of the large bogs.

Peat bogs are cool habitats relative to the surrounding terrain. Temperature within a bog can be several degrees lower than temperatures outside the bog (Spitzer and Danks 2006). We collected several subalpine, cold-adapted species e.g. Micrargus georgescuae Millidge, 1976, Robertus truncorum (L. Koch, 1872). The cool peat bogs may serve as refugium habitats for such species in low mountain ranges. Cold-adapted taxa with restricted ranges are also vulnerable to climate change (Ohlemüller et al. 2008). These species will presumably undergo range shifts towards higher altitudes in Central Europe, and are likely to disappear from lower mountain ranges at the present rate of global warming (Theurillat and Guisan 2001; Bátori et al. 2017). Thus peat bogs may constitute important micro-refugia for coldadapted species as they maintain a cooler microclimate.

Species richness and diversity was higher in birch forest bogs than in pine bogs. There is a strong relationship between the assemblage composition of spiders and environmental gradients. For Central-European spiders, shading and moisture are prominent environmental filters in shaping the distributional pattern of different species (Entling et al. 
2007). Canopy closure has a significant influence on the microclimatic conditions, such as temperature and moisture of the forest floor (Lindh and Muir 2004), thereby influencing spider species distribution (Entling et al. 2007; Ziesche and Roth 2008). We argue that birch forest species richness is higher, because birch trees have more open canopy than pine forests, and therefore create a micro-climatically patchier environment. The open patches allow open habitat specialists to occur in high densities in these forests, while species with basic preference for humid soil additionally also prefer higher surface temperature with higher insolation, resulting in an overall higher species richness of these sites. Litter type and quality may also contribute to the explanation of spider species distribution, which is correlated with the evergreen or deciduous character of the forest (Ziesche and Roth 2008). The structural complexity of litter provides web attachment points for web-building spider species (Uetz 1979). Furthermore, physical and chemical properties of litter quality affect potential prey items of spiders, such as collembola (Bolger et al. 2013; Kováč et al. 2005).

Contrary to the classical theory of island biogeography we found no significant effect of habitat area on spider assemblages. The lack of this relationship indicates that the tyrphophilic spider fauna was present even in the smallest peat bog. Several former studies of the spider fauna of natural habitat patches found that habitat size and spider fauna are often unrelated (Bonte et al. 2002; Pajunen et al. 1995; Horváth et al. 2009). The low $\mathrm{pH}$ and wet conditions of peat bogs represent environmental filters, which may preclude the colonization of generalist species, resulting in a similar spider fauna of small and large peat bogs.

Our results showed a segregation of spider assemblages at different mountain ranges. Many species proved to be nonrandomly distributed, indicating that the regional fauna of peat bogs in different mountain ranges are isolated. Several former studies also have shown that different mountain ranges within the Carpathian arc may have isolated fauna (Pauls et al. 2006; Dénes et al. 2016). Furthermore, Bálint et al. (2011) identified numerous endemic arthropod species with distribution ranges restricted to a single mountain range. Thus, the disjunct habitats of isolated mountain ranges played a major role in promoting biodiversity of the Carpathian arc (Bálint et al. 2011).

\section{Implications for conservation}

Cold-adapted and peat bog specialist species are endangered by the human induced loss of suitable habitat, as a result of land use intensification (Malcolm et al. 2006; Dirnböck et al. 2011). Forest management intensity is related to changes in the share of privately owned land in Central-Europe (Munteanu et al. 2016). In Romania, the proportion of private land has increased since 1990 and the lack of management plans for the majority of private forests resulted in high harvesting rates in the Eastern-Carpathian forests (Munteanu et al. 2016). This resulted in direct loss of bog forests and indirect deterioration of peat bog habitats due to eutrophication if the forest belt around the bogs was harvested. Luckily, the remaining nearly pristine patches offer the opportunity to identify the original invertebrate fauna. The occurrence of tyrphophilous spider species highlights the high conservation value of these oligotrophic wet habitat patches, while specific faunas by mountain regions indicate that peat bogs should be equally preserved in every region because of their unique values. Specialist spider species were abundant in both birch and pine forests emphasizing that both forest types are important for biodiversity conservation. Peat bog spider fauna requires specific habitat conditions, thus deterioration of peat bog habitats would mean losing the specialized fauna (Buchholz 2016). We suggest that preserving hydrological properties and water quality even in the smallest bogs would conserve the specialized fauna. This could be enhanced by creating unmanaged pine forest buffer areas around the remaining peat bogs.

Acknowledgements Open access funding provided by MTA Centre for Ecological Research (MTA Ö-K). We are grateful to Péter Batáry for valuable comments on the manuscript. This study was financially supported by the Institute of Research Programmes of the Sapientia Hungarian University of Transylvania and by the Domus Hungarica Scientiarum et Artium research grant, in the joint program of the Hungarian Ministry of Education and Culture and the Hungarian Academy of Sciences.

Author contributions RG and UI designed the study, RG, A-RZ, NG-S and IU did the field work, RG, N-GS and IU identified the spiders, RG analyzed the data with help from FS, RG wrote the manuscript with substantial contribution from all authors. All authors approved the final submission manuscript.

\section{Compliance with ethical standards}

Conflict of interest The authors declare that they have no conflict of interest.

Research involving human and animal participants To obtain the data presented in the manuscript it has been necessary to involve animals, however this study did not involve protected species and no human participants were involved in the work.

Informed consent All authors consent to submission of this manuscript.

Open Access This article is distributed under the terms of the Creative Commons Attribution 4.0 International License (http://creativeco mmons.org/licenses/by/4.0/), which permits unrestricted use, distribution, and reproduction in any medium, provided you give appropriate credit to the original author(s) and the source, provide a link to the Creative Commons license, and indicate if changes were made. 


\section{References}

Bálint M, Ujvárosi L, Theissinger K, Lehrian S, Mészáros N, Pauls SU (2011) The Carpathians as a major diversity hotspot in Europe. In: Zachos F, Habel J (eds) Biodiversity hotspots. Springer, Berlin, pp 189-205

Bátori Z, Vojtkó A, Farkas T, Szabó A, Havadtői K, Vojtkó AE, Tölgyesi Cs, Cseh V, Erdős L, Maák I, Keppel G (2017) Largeand small-scale environmental factors drive distributions of cool-adapted plants in karstic microrefugia. Ann Bot-London 119:301-309

Battes KP, Moldovan I, Sas A (2014) Planktonic microcrustaceans (Crustacea: Cladocera, Copepoda) from several protected peat wetlands, differing in trophic state. North-West J Zool 10:78-86

Bolger T, Kenny J, Arroyo J (2013) The Collembola fauna of Irish forests - a comparison between forest type and microhabitats within the forests. Soil Org 85:61-67

Bonte D, Baert L, Maelfait JP (2002) Spider assemblage structure and stability in a heterogeneous coastal dune system (Belgium). J Arachnol 30:331-343

Buchar J, Ruzicka J (2002) Catalogue of spiders of the Czech Republic. Peres Publisher, Praha

Buchholz S (2016) Natural peat bog remnants promote distinct spider assemblages and habitat specific traits. Ecol Indic 60:774-780

Charman DJ (2002) Peatlands and environmental change. Wiley, Chichester, p 301

Dénes AL, Kolcsár LP, Török E, Keresztes L (2016) Phylogeography of the micro-endemic Pedicia staryi group (Insecta: Diptera): evidence of relict biodiversity in the Carpathians. Biol J Linn Soc 119:719-731

Dirnböck T, Essl F, Rabitsch W (2011) Disproportional risk for habitat loss of high-altitude endemic species under climate change. Glob Change Biol 17:990-996

Doyle G (1990) Ecology and conservation of Irish Peatlands. In: Doyle G (ed) Ecology and conservation of Irish Peatlands. Royal Irish Academy, Dublin

Eggleton P, Vanbergen AJ, Jones DT, Lambert MC, Rockett C, Hammond PM, Beccaloni J, Marriott D, Ross E, Giusti A (2005) Assemblages of soil macrofauna across a Scottish land-use intensification gradient: influences of habitat quality, heterogeneity and area. J Appl Ecol 42:1153-1164

Entling W, Schmidt MH, Bacher S, Brandl R, Nentwig W (2007) Niche properties of Central European spiders: shading, moisture and the evolution of the habitat niche. Glob Ecol Biogeogr 16:440-448

Gallé R, Urák I (2001) Contribution to the spiders (Arachnida: Araneae) of upper Mureş river valley with some new data for the Romanian fauna. Entomol Romanica 6:141-145

Gallé R, Urák I (2002) Faunistical data on the spiders (Arachnida: Araneae) of the Nemira Montain's bog complex with two new species for the Romanian fauna. Entomol Romanica 7:85-88

Gallé R, Urák I (2006) Faunistical data on the spiders (Arachnida: Araneae) of the Lacul Dracului bog complex with new data for the Romanian fauna. Sci Ann Danube Delta Inst 12:29-32

Gibb H, Hochuli DF (2002) Habitat fragmentation in an urban environment: large and small fragments support different arthropod assemblages. Biol Conserv 106:91-100

Haase H, Balkenhol B (2014) Spiders (Araneae) as subtle indicators for successional stages in peat bogs. Wetl Ecol Manag 23:453-466

Horváth R, Magura T, Szinetar C, Tóthmérész B (2009) Spiders are not less diverse in small and isolated grasslands, but less diverse in overgrazed grasslands: a field study (East Hungary, Nyirseg). Agric Ecosyst Environ 130:16-22
Hsieh TC, Ma KH, Chao A (2016) iNEXT: an R package for rarefaction and extrapolation of species diversity (Hill numbers). Methods Ecol Evol 7:1451-1456

Keddy PA (2010) Wetland ecology: principles and conservation. Cambridge University Press, Cambridge

Koponen S (2002) Ground-living spiders in bogs in northern Europe. J Arachnol 30:262-267

Kováč LU, Kostúrová N, Miklisová D (2005) Comparison of collembolan assemblages (Hexapoda, Collembola) of thermophilous oak woods and Pinus nigra plantations in the Slovak Karst (Slovakia). Pedobiologia 49:29-40

Kupryjanowicz J, Hajdamowicz I, Stankiewicz A, Starega W (1997) Spiders of some raised peat bogs in Poland. In: Selden (ed) Proceedings of the 17th European colloquium of arachnology, Edinburgh, pp 267-272

Kurka A (1990) The arachnofauna of Bohemian peat bogs. Spiders (Araneida) of the State Nature Reserve Mrtvy Luh, Sumava Mts. Acta Musei Nationalis Pragae B 46:37-77

Legendre P, Gallagher ED (2001) Ecologically meaningful transformations for ordination of species data. Oecologia 129:271-280

Lindh BC, Muir PS (2004) Understory vegetation in young Douglas-fir forests: does thinning help restore old-growth composition? For Ecol Manag 192:285-296

Malcolm JR, Liu C, Neilson RP, Hansen L, Hannah L (2006) Global warming and extinctions of endemic species from biodiversity hotspots. Conserv Biol 20:538-548

Mráz P, Gaudeul M, Rioux D, Gielly L, Choler P, Taberlet P, IntraBioDiv Consortium (2007) Genetic structure of Hypochaeris uniflora (Asteraceae) suggests vicariance in the Carpathians and rapid post-glacial colonization of the Alps from an eastern Alpine refugium. J Biogeogr 34(12):2100-2114

Munteanu C, Nita MD, Abrudan IV, Radeloff VC (2016) Historical forest management in Romania is imposing strong legacies on contemporary forests and their management. For Ecol Manag 361:179-193

Nentwig W, Blick T, Gloor D, Hänggi A, Kropf C (2017) Spiders of Europe. Version 03.2017. http://www.araneae.nmbe.ch. Accessed 20 June 2017

Ohlemüller R, Anderson BJ, Araújo MB, Butchart SH, Kudrna O, Ridgely RS, Thomas CD (2008) The coincidence of climatic and species rarity: high risk to small-range species from climate change. Biol Lett 4:568-572

Oksanen J, Blanchet FG, Kindt R, Legendre P, Minchin PR, O'Hara B, Simpson GL, Solymos P, Stevens MH, Wagner H (2015) The Vegan Package, Version 2.2-1. http://cran.r-project.org/web/packa ges/vegan/index.html. Accessed 12 Oct 2018

Pajunen T, Haila Y, Halme E, Niemelà J, Punttila P (1995) Grounddwelling spiders (Arachnida, Araneae) in fragmented old forests and surrounding managed forests in southern Finland. Ecography 18:62-72

Pauls SU, Lumbsch HT, Haase P (2006) Phylogeography of the montane caddisfly Drusus discolor: evidence for multiple refugia and periglacial survival. Mol Ecol 15:2153-2169

Platnick NI (2018) World Spider Catalog (2018). World Spider Catalog. Version 19.5. Natural History Museum Bern. http://wsc. nmbe.ch. Accessed 26 Sept 2018

Pop E (1960) Mlaştinile de turbă din Republica Populară Română, Ed. Acad. Rep. Pop. Rom., Bucureşti

Relys V, Koponen S, Dapkus D (2002) Annual differences and species turnover in peat bog spider communities. J Arachnol 30:416-424

Riecken U, Finck P, Raths U, Schröder E, Ssymank A (2006) Rote Liste der gefa" hrdeten Biotoptypen Deutschlands. Zweite fortgeschriebene Fassung 2006. Naturschutz und biologische Vielfalt 34:1-318 
Roberts DW (2015) Package "labdsv". Ordination and multivariate analysis for ecology. https://cran.r-project.org/web/packages/labds v/labdsv.pdf

Samu F, Urák I (2014) Are more bogs better? Comparative studies into Transylvanian peat bog spider (Arachnida: Araneae) assemblages from a conservation biological perspective. North-West J Zool 10:94-101

Scott AG, Oxford GS, Selden PA (2006) Epigeic spiders as ecological indicators of conservation value for peat. Biol Conserv 127:420-428

Spitzer K, Danks HV (2006) Insect biodiversity of boreal peat bogs. Annu Rev Entomol 51:137-161

Štambuk A, Erben R (2002) Wolf spiders (Araneae: Lycosidae) on the overgrowing peat bog in Dubravica (north-western Croatia). Arachnologische Mitteilungen 24:19-34

R Core Team (2016) R: a language and environment for statistical computing. R Foundation for Statistical Computing, Vienna. https ://www.r-project.org/. Accessed 12 Oct 2018

Theurillat JP, Guisan A (2001) Potential impact of climate change on vegetation in the European Alps. Clim Change 50:77-109

Uetz GW (1979) The influence of variation in litter habitats on spider communities. Oecologia 40:29-42
Urák I, Samu F (2008) Contribution to the spider fauna of the Mohoş peat bog from Transylvania, with some new data for Romania. North-West J Zool 4:50-60

Urák I, Hartel T, Gallé R, Balog A (2017) Worldwide peatland degradations and the related carbon dioxide emissions: the importance of policy regulations. Environ Sci Policy 69:57-64

Weiss I, Urák I (2000) Faunenlisten der Spinnen Rumäniens (Arachnida: Araneae). http://www.arachnologie.info. Accessed 16 Oct 2018

Więcek M, Martin P, Gąnka M (2013) Distribution patterns and environmental correlates of water mites (Hydrachnidia, Acari) in peatland microhabitats. Exp Appl Acarol 61:147-160

Ziesche TM, Roth M (2008) Influence of environmental parameters on small-scale distribution of soil-dwelling spiders in forests: what makes the difference, tree species or microhabitat? For Ecol Manag 255:738-752

Publisher's Note Springer Nature remains neutral with regard to jurisdictional claims in published maps and institutional affiliations. 